\title{
Effect of Cost Leadership Policy on Institutional Performance of Public Universities in Kenya
}

\author{
Laura Wanjiku Ikatwa ${ }^{1} *, \&$ Barrack Okello ${ }^{2}$ \\ ${ }^{I}$ The Corresponding Author is a Master of Business Administration (Strategic Management) at Jomo Kenyatta \\ University of Agriculture and Technology, Nakuru Campus, Kenya. \\ ${ }^{2}$ Barrack Okello is a lecturer at Jomo Kenyatta University of Agriculture and Technology, Nakuru Campus, \\ Kenya.
}

\begin{abstract}
The Kenyan higher education sector has been rapidly expanding in terms of student enrolments. Available statistics shows rapidly expanding higher education sector student enrolments levels from each year. The expansion in the higher education sector is also experienced across private institutions. These rapid expansions of the university population as well as the university numbers have created an extremely competitive environment. The Kenyan higher education sector, the largest within East Africa, is operating in a hyper competitive environment due to the rising number of the universities, university colleges and university satellite campuses spread across different towns. The cost leadership policy is among the strategies that universities have adopted. This study seeks to examine the effect of various cost policy aspects that is pricing policy, scale policy, and structure centralization on institutional policy at public universities in Kenya. The theoretical framework is based on the Bowman's strategy clock, dynamics capabilities theory, and Michael porter's generic strategies. The descriptive research design will be utilized for the study. The target population constituted of the principals, deans and directors of diverse public universities. A sample size of 87 respondents was used for the study. Structured questionnaires were used for the data collection. The SPSS version 22 was used for the analysis of both descriptive and inferential statistics. The descriptive statistics that will be used include standard deviations and means. The study also found a statistical significance between pricing policy and institutional performance of public universities in Kenya. The study also found a statistical significance between scale policy and institutional performance of public universities in Kenya. The study found a statistical significance between structure centralization policy and institutional performance of public universities in Kenya. The multiple correlation effect of 0.947 indicates a relatively strong positive relationship effect between the three independent variables (pricing policy, scale policy and institutional policy) and the dependent variable (institutional performance). The coefficient of determination ( $R$ Square) indicates the variance on the dependent variable attributed to the four independent variables. In this context, the coefficient of determination ( $R$ Square) of 0.896 indicates that the three independent variables contributed to $89.6 \%$ of the variance in dependent variable.
\end{abstract}

Keywords: Cost Leadership, Pricing Policy, Scale Policy

\section{Introduction}

The cost leadership policy involves the lowering of costs as well as providing value for customers to gain competitive strategy in an extremely competitive environment. The firms adopting this strategy often offer relatively standardized products with acceptable to customers with minimal differentiation (Mnjala, 2014). For the cost leadership strategy to be sustainable, the firm must reduce on the operational costs, faster mover advantage, winning of the price war, and market dominance (Anyim, 2012). The cost reduction strategies that the firms can utilize include building efficient-scale facilities, establishing tight control of production and overhead costs, minimizing the costs of sales, product research and development, reduced margins and investing in state-of-the-art manufacturing technologies (Riungu, 2013). The firm must also link the primary and secondary value creating activities through simplification of processes and procedures, achieving efficiency and effectiveness, reducing costs, monitoring the costs of activities provided by others that interface with the company's inbound and outbound logistics (Sirengo, 2009). The activities that constitute the value chain must be undertaken in manner that utilizes the available resources effectively through aggressive construction of efficient-scale facilities, vigorous pursuit of cost reductions from experience, tight cost and overhead control, avoiding of marginal customer accounts and cost minimization in areas of research and development, service, sales force and advertising (Chepkiyeng, 2009). In summary, the cost leadership is a strategy used by businesses to create a low cost of operation within their niche with the primary objective of gaining advantage over competitors; this is achieved by reducing operating costs below that of others in the same industry.

According to Munyaka (2013) defines performance as the outcome of all the organization's operations and strategies or the extent to which an organization achieves a set pre-defined targets that are unique to its 
markets (Muia, 2012; Munyaka, 2013; Muthike, 2014). On the other hand, Institutional performance is defined as a measure of how well an organization achieves its own vision through the fulfillment of its set goals and objectives that may be financial and/or non- financial that is a measure of organization's actual output or results against its intended outputs (or goals and objectives) (Naisiae, 2013). The concept of the Institutional performance is based upon the idea that an organization is the voluntary association of productive assets, including human, physical, and capital resources, for achieving a shared purpose (Mucai, Kinya, Noor, \& James, 2014). Mbithi (2014) defines Institutional performance as the achievement of high levels of performance, profitability and customer satisfaction by enhancing skills and engaging the enthusiasm of employees.

The Institutional performance has been conceptualized from two perspectives; financial perspective and the non-financial perspectives (Muthoni, 2013). The traditional means of measuring the Institutional performance was through the financial measurements only (Gitau, 2014). The financial performance approach examines indicators such as sales growth, profit rate, return on investment, return on sales, return on equity, and earnings per share (Abdi, 2014). However, Muriithi (2010) note that the financial performance as a measure of Institutional performance has become inadequate for the new reality of organizations given accelerated changes in technology, needs for innovation, flexibility, shortened product life cycles. The non-financial performance approach focuses on market share, new product introduction, product quality, marketing effectiveness and technological efficiency (Chepkiyeng, 2009). Some scholars have further expanded the non-financial matrix of Institutional performance. In this context, Nyongesa (2014) argues that there are four classifications of the company's performance. This includes the financial performance, internal business process performance, client performance and learning growth performance. The internal business process performance is involved with the improvement of the innovation and operational process (Irungu, 2010). The learning growth performance is concerned with the improvement of the personnel capability, improvement of the information system capability, personnel development and compatibility (Imaana, 2011).

There are two broad ways of measuring Institutional performance. This includes the use of performance management systems and the consensual measurement of performance (Kuria, 2013).The performance management systems provide the foundation to develop strategic plans, assess an organization's completion of objectives, and remunerate managers (Ogoye, 2013). On the other hand, the consensual measurement of performance promotes scholarly investigations and can clarify managerial decisions, marketers have not been able to find clear, current and reliable measures of performance on which marketing merit could be judged (Gikunda, 2014). New performance measurement frameworks that accommodate both the financial and non-financial measurements have been introduced. This includes the balanced score card, integrated performance measurement, shareholder model and the performance management framework (Nyongesa, 2014). Some scholars such as Lewis in 1955 while undertaking a study on General Electric (GE) advocated for a mixture of the financial and non-financial performance measures (Kiptui, 2012). This mixture recommended the Institutional performance to be measured through one financial and seven nonfinancial metrics namely Profitability, Market share, Productivity, Product leadership, Public responsibility, Personnel development, Employee attitudes and Balance between short-range and long-range objectives (Mwandebe, 2009).

The need for cost policy for institutional performance is closely tied to the metric of student enrollment as a measurement for institutional performance. This has been occasioned by the rapid increase in the competition in the university sector occasioned by high enrollment rates across the world, regional and Kenyan universities (Mutiso, 2013).

The higher education sector at a global stage has rapidly expanded, a phenomenon that education specialists call massification of education, in the last century. In this context, the higher education has ceased being the preserve of the elites, accessed by largely the privileged groups such as the rich, to a global industry annually enrolling millions of students (Muthimi, 2013). In 1900, there were roughly 500,000 students enrolled in higher education institutions around the world that represented $1 \%$ of the university age population by then. This figure had grown into 68 million by the year 1991, 100 million by year 2000, 132 million by the year 2004, and 178 million by the year 2010 (Kitum, 2010).

The competition for students is intense in the developed world creating a need for creation of competitive strategies in order to attract students faced with too many options (Agumbi, 2013). For example, the United Kingdom (UK) had 162 universities serving 2.3 million university students in the 2012/2013 academic year. The intense competition for students is due to the increasing number of universities in close proximity to each other in major towns such as London, Oxford, Leeds and Sheffield cities amongst others. In London alone, there are over 40 universities within the M25 and more new one set to be opened. The intense competition has seen the universities adopt strategies to remain profitable and competitive in attracting students. Some of the activities done to this end include research, conference organization, offering career advice, financing startup companies, maintaining historic buildings and promoting sport (Katamei, 2015).

The Kenyan higher education sector has been rapidly expanding in terms of student enrolments. Available statistics shows rapidly expanding higher education sector student enrolments levels from 67,558 
(2003/2004 academic year), 198,260 (2011/2012 academic year), 340,550 (2014/2015 academic year), to 769,550 (2015/2016 academic year). The expansion in the higher education sector is also experienced across the gender lines and across private institutions. For example, the female student enrollment rose by $30.5 \%$ from 80,560 in $2011 / 2012$ to 186,115 in 2012/2013 academic years. On the other hand, the enrollment in private universities rose by $11.6 \%$ from 40,344 in 2011/2012 academic year to 95,023 in the 2013/2014 academic year (Oduor et al., 2015). The Kenyan higher education sector operates in a hyper competitive environment due to the rising number of the universities, university colleges and university satellite campuses spread across different towns. In the last decade, the number of the universities has expanded from 20 fully fledged universities in 2000 to the current 70 universities in Kenya (Katamei, 2015). The public universities have decried the declining levels of funding to support its research activities. The specific universities must therefore seek strategies to create and enhance their competitive advantage in order to gain and retain market share hence remaining profitable (Annor, 2012). The cost leadership policy is among the strategies that universities have adopted. The need to adopt a competitive strategy is informed by the need to create an advantageous position to meet the customers' expectations. This is to enable the company take an offensive or defensive action in order to create a defendable position against the five competitive forces and involves positioning the firm so that its capabilities provide the best defense against these forces. This study wishes to examine the various ways in which the cost policy has been used in public universities to enhance the institutional performance.

\section{Theoretical Review}

\section{Literature Review}

The theoretical review was undertaken through the strategy clock. Bowman and D'Aveni introduced the concept of the strategy clock in 1995 to demonstrate that organizations can achieve competitive advantage through providing their customers with what they want, or need, more effectively than competitors. The customers in this context make their choices to purchase based on their perception of value for money (Mnjala, 2014). Therefore, the bowman's strategy clock combines the aspect of price and the customer perceived product or service benefits of the service or product (Ndanu, 2014). In this context, assuming that the products or services of different businesses are more or less equally available, customers may choose either because: the price of the product or service is lower than a competitor's or the product or service is perceived by the customer to provide better "added value" than that available elsewhere (Wu, 2010).

The route 1 described as the no frills strategy is a combination of the low price, low perceived added value and focus on a price sensitive market segment. This is idea strategy for the for the market which the participants cannot afford to but better quality goods and as such are contented with the low price and therefore low quality goods (Sirengo, 2009). The university in this segment needs high volumes of business for the model to be sustainable. The route 2 is the low price strategy which seeks to achieve a lower price than competition while still maintaining similar value of product or service to that offered by the competition. These categories of firms seek to balance the low prices with high margins but at a risk of a price war which is only sustainable in the short term (Waema, 2013). Route 3 is a "hybrid strategy" which seeks simultaneously to achieve differentiation and a price lower than that of competitors. The success of the strategy depends on the ability both to understand and to deliver enhanced value in terms of customer needs, while having a cost base that permits low prices and is sufficient for reinvestment to maintain and develop bases of differentiation (Sifuna, 2014). These companies offer products at low cost but offer products with a higher perceived value than the route two companies (low price strategy). Route 4 is a broad "differentiation strategy" which seeks to provide products or services unique or different from those of competitors in terms of dimension widely valued by buyers. The aim is to achieve either higher market share than competitors by offering better products or services at the same price, or enhanced margins by pricing slightly higher. To be able to afford to do this, there is need for the universities to either increase their price or sustain themselves through higher margins, or they keep their prices low and seek greater market share. Branding is important with differentiation strategies as it allows a company to become synonymous with quality as well as a price point (Mulwa, 2010). Route 5 is a "focused differentiation strategy" which seeks to provide high perceived value justifying a substantial price premium. Consumers will buy in this category based on perceived value alone. The product does not necessarily have to have any more real value, but the perception of value is enough to charge very large premiums (Yoon, 2012). Route 6 suggests increasing price without increasing value to the customer. If the price change is accepted by the market, the companies enjoy higher profitability but it is often unsustainable due to market forces. Route 7 involves the reduction in value of a product or service, while increasing relative price. Route 8 is concerned with a reduction in value while maintaining price.

The Bowman's Strategy Clock is applicable in this study in the context that universities pursue different strategies with a view of utilizing the cost leadership policy. Some of these ways include relatively low cost of service in terms of school fees and statutory payments within the universities while then pursuing a no frills strategy. This approaches such as the one pursued by Mount Kenya University involves a low pricing 
strategy with view of sensitivity of the pricing aspects. A perception of low quality must also be there. Some of the universities may also pursue a differentiation strategy that seeks to provide that seeks to provide high perceived value justifying a substantial price premium. Consumers will buy in this category based on perceived value alone. The product does not necessarily have to have any more real value, but the perception of value is enough to charge very large premiums. Strathmore University is an example of a university pursuing this strategy.

\section{Pricing Policy}

The low prices (school fees) can be described as the strategic pricing. The strategic pricing create huge demand (hence volumes) resulting into lower margins per student which are compensated by the high volumes of students (Omollo, 2013). The strategic pricing is competitive through allowing for profit and working back to make the cost target. The university has to then put efforts towards providing its services on the cost target without losing utility or increasing price (Muthimi, 2013). This can be achieved through digitization of some of the processes and removal of low value addition activities.

The price based strategy such as the one pursued at diverse universities can take two directions that is the no frills strategy and the low price strategy. The no frills strategy combines the low price, low perceived product or service benefits and a focus on price sensitive market segment (Wanyonyi, 2012). This is often ideal if the customers cannot discern or value differences in the courses taught by different universities (Nkirote, 2014). In this context, Mount Kenya University for example has often been accused of low education standards leading to the cancellation of its programs at its Kigali campus. The university had five courses at the Kigali campus temporarily suspended by the authorities in Rwanda for not meeting the threshold standards set in the county for health related courses.

On the other hand, the low price strategy seeks to achieve a lower pricing at the MKU compared to other universities whilst trying to maintain similar perceived products or service benefits to those offered by the other universities. If a business unit aims to achieve competitive advantage through low pricing strategy, it has to try to identify and focus on a market segment that is unattractive to competitors and in this way avoid competitive pressures to erode price (Waiganjo, 2013). In this context, MKU has opened campuses in areas perceived to be unattractive such as Lodwar and Hargeisa in Somalia. The university has also ventured into science and technology related studies contrary to the private universities focus on the social sciences programs only. In this context, the MKU became the first local private university to graduate pharmacy students in the country. Firms that implement a cost leadership strategy are able to secure relatively large market share by being the lowest cost producers and service providers in their industry or market (Nyakango, 2013). In this context, MKU has been able to establish itself to have the largest student population among the private universities as well as the largest private university in the country. By pursuing low costs, universities not only operate efficiently, but also become an effective price leader, undermining competitors' growth in the industry through its success at price war and undercutting the profitability of competitors, then the firm can offer lower prices, higher quality, or both.

According to Ngati (2014) in a study Positioning Strategy as a Source of Competitive Advantage to Private Universities in Kenya found that only $15.4 \%$ of the universities in Kenya utilized cost leadership strategy. The aspects examined included the university specialize in serving the needs of particular student segments (e.g. religious background, income level) or in particular geographical segments, and the university specialize in providing particular types of courses which are market oriented and popular with both local and international employers. Others were the university is different based on the quality of services it offers as well as university brand image is well entrenched regionally and this has attracted students from the international market. Other metrics included university engagement in social responsibility activities has enabled it to be popular in the country and the university has budgeted and utilizes greater advertising funds from one year to another than competitor.In the context of the low pricing strategy, Sathyamoorthi (2016) in the examination of low pricing strategies within the context of supermarket noted two low pricing strategies. These low pricing strategies included the Everyday Low Price and the High-Low pricing strategy. The Everyday Low Price means that the retailer promises the customer low prices across a variety of services and is not pegged to promotions or discounts. On the other hand, the High-Low Pricing includes high pricing of some items than the market rate and low pricing of selected items. The strategy is characterized by deep discounting on selected categories of items at different intervals throughout the year. The logic behind this approach is the hope that whilst the customers are attracted to buy low-price items, they may end up buying some high-price items as well.

\section{Scale Policy}

The element of cost is closely associated with the size of the university and its scale operations. The universities in provision of education must ensure efficiency of resources utilization in order to keep the cost of operations down. The elements affecting the cost minimization include the quantity and quality of output, 
whether to specialize or produce multiple outputs or whether the institution should be small or large in either student enrolment or research. Which way the universities decide, the economies of scale is one critical way of cost reduction. The economies of scale are a source of cost advantage to any institution. According to Tholkes \& Sederberg (2015), the economies of scale is a curvilinear relationship between average cost and the number of units produced. The economies of scale are achieved through specialization in use of resources, spreading costs over more output units, and the growth of ancillary facilities.

Tholkes \& Sederberg (2015) the economies of scale are used within the context of the universities and other educational institutional with a view of minimizing the unit of cost of service provision. The application of the economies of scale principle in the public universities requires the definition of the function, nature, inputs, and outputs of school organizations, and of the university output capacity. The purpose of the universities is the delivery of the instructional and support services. In this context, the university organizational inputs are the factors of production necessary for the generation of educational services that is personnel, facilities, and equipment (Mukokho, 2010). The economies of scale within the context of the learning institution are the administrative production function in which each course, co-curricular activity, and support service is treated as an output. The school's output capacity is defined as the maximum number of students who can be offered a specified mix of instructional and support services at given levels of class sizes and staffing ratios (Riechi, 2013). The average costs are measured as the monetary value of the inputs required to offer a particular service divided by the number of service units provided. The total of these average costs for all programs constitutes the average cost of the university. The economies of scale are realized for a particular service as long as the addition of one more student results in a lower average cost per instructional contact hour or other unit of service. For the university, economies of scale are realized as long as one service experiences lower average total costs by enrolling one more student (Kinanga, 2013). Economies of scale are maximized at the point where the combined average total costs of all services are at their minimum on the universities' scale curve.

The size of the university is a source of cost advantage as there is the relationship between firm size measured in terms of volume of production - and costs - measured in terms of average costs per unit of production (Wanjohi, 2012). In the context of the economies of scale, the size of the university is measured in terms of student enrolment and economies of scale arise when the cost of providing education falls as the student enrolment or size of the university increases. In most universities, the student enrolment levels in either the undergraduate or postgraduate level and the associated teaching output is the essential contributor of costs. In the short term, the universities can achieve economies of scale by lowering quality and boosting quantity (student enrolment), but in the long term the quality of instruction and research output also influence the university cost structure and are vital determinants of economies of scale in higher education (Mwangi, 2013). The optimal volume of production is reached when the average costs per unit of production is minimum. Universities with high degree courses and student numbers are able to purchase and utilize services that cannot be used in smaller universities. Cost leadership strategies have traditionally been based upon the economies of scale, gained through sales volume (Imaana, 2011). However, if volume is to be the basis for cost leadership then it is preferable for that volume to be gained early in the market life cycle.

Tirivayi, Groot, \& Brink (2009) examined the application of the economies of scale within the context of the United States universities. The study reviewed the size-cost relationship of university education in the United States and concluded that economies of scale are most likely to occur at the low end of student enrolment range i.e. 1000 full time equivalent students in two year colleges and 1500-2000 full time equivalent students in four year colleges. However, they also determined that nature and strength of the economies of scale were not only influenced by size, but also by other factors such as the type of institution, type of costs (administrative vs. instructional), input prices like salaries paid and breadth of curriculum.

\section{Structure Policy}

The structure centralization is the process by which the activities of an organization become concentrated within a particular location. The structure centralization refers to the number of locations at which similar activities are carried out with a centralized network meaning that each activity is installed at a few locations only. On the other hand, the decentralized network means that the same operation is carried out at several different locations in parallel. There are several factors that influence the centralization of certain services.

There are certain factors that can be centralized within a university set up. Some aspects of the distribution are more cost effective in a centralized set up as opposed to a decentralized set up. The distribution describes all the logistics involved in the delivery of a company's products or services to the right place, at the right time, for the lowest cost (Yongtao, 2009). It is the process of making a product or service available for use or consumption by a consumer or business user, using direct means, or using indirect means with intermediaries. The distribution channels are a critical component for creating sustainable competitive advantage since place is one critical factor of the marketing matrix. Choosing the right distribution channel to move products or services 
to the end user is a long-term strategic decision and varies according to the product, service and market (Waiganjo, 2013). When choosing a distribution strategy, a marketer must determine what value a channel member adds to the firm's products and/or service. A well-chosen channel is necessary because it constitutes a significant competitive advantage and is designed to save on cost, improve and increase efficiency, provide routinization of transactions, provide a larger customer base, and allows businesses to focus on other aspects of the organization (Yoon, 2012). It is important that the channel also provide businesses with strategic promotion, brand strategy, and provide convenience for customers while bridging the gap between the assortment of goods and services generated by producers and those in demand from consumers.

Amongst the aspects of the distribution channels that are cost effective in a centralization manner is the training of the science oriented courses. The science oriented courses such as medicine, and engineering courses are often cost intensive due to the need to establish laboratories as well extensive library with rare and expensive reading materials. In this context, due to the nature of the costs associated with putting up the facilities as well as running the courses, it is more cost effective if the same is provided in a centralized location as opposed to attempting to provide the same in each of the campuses that a university has (Messah \& Immaculate, 2011). On the other hand, the demand for the science oriented courses is low in comparison to the business-oriented courses in the universities across the country. This means that it is more cost effective for a centralized location to pool students from diverse locations into a central place (Mbithi, 2014).

There is also a host of administrative related functions that are cost effective when centralized as opposed to decentralized. The universities need to advertise and market their services to potential students across the country. However, the cost saving as a result of economies of scale would be lost if each of the campuses of the university across the country did their own marketing services. Therefore, such services are better off centralized to one location for ease of execution as well as cost saving. Other administrative and operational aspects that can be centralized include accounting and graduation services.

\section{Institutional Performance}

There are diverse ways of measuring the institutional performance within the context of the universities. The private universities are purely profit making entities while the public universities have had a need to supplement their funding through diverse programs such as parallel degrees or self-sponsored degree programs (Agumbi, 2013). In this context, the universities must seek to attract and retain students at undergraduate level with a view of increasing their income revenue streams. On the other hand, there is a huge demand for the post graduate level education especially for the Masters' of Business Administration (MBA) which creates a critical revenue stream for the universities (Katamei, 2015). The ability to attract these postgraduate students is a key institutional performance metric. Finally, the services that the universities sell is the different courses and program hence their intake is another performance metric.

\section{Objective of The Study}

The specific research objectives were as follows;

1. To examine the influence of the pricing policy on the Institutional performance in public universities in Kenya

2. To analyze the effect of scale policy on the Institutional performance in public universities in Kenya

3. To determine the influence of structure policy on the Institutional performance in public universities in Kenya

\section{Research Hypotheses}

The research hypotheses were as follows;

$\mathbf{H}_{01}$ : There is no significant relationship between pricing policy and institutional performance in public universities in Kenya

$\mathbf{H}_{\mathbf{0 2}}$ : There is no significant relationship between scale policy and the institutional performance in public universities in Kenya

$\mathbf{H}_{\mathbf{0 3}}$ : There is no significant relationship between structure policy and the institutional performance in public universities in Kenya

\section{Methodology}

The descriptive survey research design was used for this study so as to examine a diverse range of universities. The quantitative research approach was used in this study. The quantitative research approach is ideal due to the ease of data collection and analysis through use of software such as SPSS. The study was through primary method as the researcher will go to the filed for data collection. The target population was the deans, principals and directors of the diverse universities. According to Mwangi (2013), there are about 687 deans and principals across the Kenyan universities. According to Mwangi (2013), there are about 687 deans 
and principals across the Kenyan universities. This study employed Nassiuma's (2009) formula to calculate the size of the sample. The formula to scientifically derive the sample from the target population is illustrated hereunder.

$$
\begin{gathered}
n=\frac{N C^{2}}{C^{2}+(N-1) e^{2}} \quad \text { Where } \\
\mathrm{n}=\text { sample size } \\
\mathrm{N}=\text { size of target population } \\
\mathrm{C}=\text { coefficient of variation }(0.5) \\
e=\text { error margin }(0.05)
\end{gathered}
$$

Substituting these values in the equation, estimated sample size (n) will be:

$\mathrm{n} \quad=687(0.5)^{2} /\left(0.5^{2}+(687-1) 0.05^{2}\right)$

$\mathrm{n} \quad=\quad 87$ respondents

The deans, principals and directors of diverse public universities were used as the target population in which a sample size of 87 respondents was used. Out of the distributed questionnaires, 73 questionnaires were returned with 14 questionnaires being unreturned. The unreturned questionnaires were attributed to some of respondents' lack of time to fill the questionnaire due to office engagement. The response rate was therefore 83.9\% which was deemed sufficient since Mugenda and Mugenda (1999) indicates that a response rate above $80 \%$ is deemed sufficient.

\section{Pricing Policy Effect on Institutional Performance}

\begin{tabular}{|c|c|c|c|c|c|c|}
\hline & Pricing Policy & $\mathbf{S A}$ & $\mathbf{A}$ & $\overline{\mathbf{U}}$ & D & SD \\
\hline 1) & $\begin{array}{l}\text { The students join my University due to the low school fees needed for } \\
\text { education program }\end{array}$ & 45.8 & 30.1 & 16.9 & 7.2 & 0.0 \\
\hline 2) & $\begin{array}{l}\text { My University provides adequate learning materials hence reducing the cost } \\
\text { of learning at their institution }\end{array}$ & 31.5 & 43.8 & 15.1 & 6.8 & 2.7 \\
\hline 3) & $\begin{array}{l}\text { My University has low statutory payments at point of admission such as } \\
\text { activity fees, ID charges, admission fees etc. }\end{array}$ & 31.5 & 43.8 & 13.7 & 11.0 & 0.0 \\
\hline 4) & $\begin{array}{l}\text { My University has few items that need to be bought at the point of entry or } \\
\text { during the course of learning hence lower costs }\end{array}$ & 64.4 & 28.8 & 6.8 & 0.0 & 0.0 \\
\hline 5) & $\begin{array}{l}\text { My University has flexible payment options that lowers the overall cost } \\
\text { burden per month }\end{array}$ & 2.7 & 11.0 & 20.5 & 49.3 & 16.4 \\
\hline
\end{tabular}

\section{Findings And Discussions}

The result for the frequency distribution of pricing policy effect on institutional performance was examined through use of table 1 below;

Table 1; Frequency Distribution of Pricing Policy in percentages

The pricing policy effect on the institutional performance was examined using five metrics that is low school fees, adequacy of materials, low statutory payments, few items to be bought, and flexibility of the payments methods. In the context of low school fees being the reason why the students join the public universities, a cumulative percentage of $75.9 \%$ of the respondents were affirmative while $7.2 \%$ of the respondents disagreed. The public universities have relatively lower school fees compared to their private universities counterpart especially for the government sponsored students. This is the therefore the reason why joining of the university due to low school fees makes it attractive especially for students from poor backgrounds.

The adequacy of the learning materials as a reason for joining the public university was agreed upon by $75.3 \%$ of the respondents with only a small percentage of $2.7 \%$ disagreeing. This is explained by the fact that a majority of the public universities have been there for a relatively long time while some of the new public universities were constituent colleges of older public universities. This lengthier period of operations implies that a majority of these universities have been able to accumulate resources over a period of time hence making them attractive for the students. In the context of the university having low statutory payments ate admission level being the reason for joining the public university, a majority of $43.8 \%$ of the respondents agreed with a further $31.5 \%$ of the respondents strongly agreeing. It was only a small percentage of $11.0 \%$ of the respondents who disagreed. The public universities are government entities not operating for commercial purposes and as such operate in a no frills model. These imply lower statutory requirements.

In the context of the lower requirements at entry point leading to institutional performance, a cumulative percentage of $93.2 \%$ of the respondents were affirmative that it contributed to institutional performance. The public universities are attractive to students especially from lower social economic 
backgrounds due to low requirements required at the point of entry as a results of their no frills operational model. Finally, in relations to the flexibility of the payment options, a majority of $49.3 \%$ of the respondents disagreed that the university had flexibility of payment options. A further $16.4 \%$ of the respondents further strongly disagreed that the university had flexible payments leading to the lowering of the overall cost burden per month.The mean and standard deviation of pricing policy were examined through the use of table 2 below;

Table 2; Mean and Standard Deviation of Pricing Policy

\begin{tabular}{|c|c|c|c|c|c|}
\hline & $\mathbf{N}$ & Min & Max & Mean & Std. Dev. \\
\hline $\begin{array}{l}\text { The students join my University due to the low school fees needed for } \\
\text { education program }\end{array}$ & 73 & 1 & 5 & 4.14 & 0.95 \\
\hline $\begin{array}{l}\text { My University provides adequate learning materials hence reducing the } \\
\text { cost of learning at their institution }\end{array}$ & 73 & 1 & 5 & 3.94 & 0.99 \\
\hline $\begin{array}{l}\text { My University has low statutory payments at point of admission such as } \\
\text { activity fees, ID charges, admission fees etc. }\end{array}$ & 73 & 2 & 5 & 3.95 & 0.94 \\
\hline $\begin{array}{l}\text { My University has few items that need to be bought at the point of entry } \\
\text { or during the course of learning hence lower costs }\end{array}$ & 73 & 3 & 5 & 4.57 & 0.62 \\
\hline $\begin{array}{l}\text { My University has flexible payment options that lowers the overall cost } \\
\text { burden per month }\end{array}$ & 73 & 1 & 5 & 2.34 & 0.97 \\
\hline Valid N (listwise) & 73 & & & & \\
\hline
\end{tabular}

The means and standard deviation of pricing policy were examined as illustrated in table 2 above. The mean and standard deviation of the students joining the university due to the low school fees needed were 4.14 and 0.95 respectively. This implied that on average the respondents agreed that the reason for joining the public university was due to low school fees. Similarly, the university providing adequate learning materials hence reduction of the cost of learning at the university had the respondents on average agreeing due to a mean of 3.94 and standard deviation of 0.99 . The respondents tended to agree that the university had low statutory payments at point of admission due to a mean of 3.95 and standard deviation 0.94 . On the other hand, the respondents on average tended to strongly agree that the university had few items that needed to be bought at the point of entry hence lowering the cost of learning due to a mean of 4.57 and a standard deviation of 0.62 . Finally, the respondents on average tended to disagree that the university had flexibility of payment options hence lowering the cost burden per month due to a mean of 2.34 and a standard deviation of 0.97 .

\section{Effect of Scale Policy on Institutional Performance}

The frequency distribution was examined using table 3 below.

Table 3; Frequency Distribution of Scale Policy in Percentages

\begin{tabular}{|c|c|c|c|c|c|c|}
\hline & Scale Policy & SA & $\mathbf{A}$ & $\mathbf{U}$ & D & SD \\
\hline 6) & $\begin{array}{l}\text { My University has a large student population hence lowering the overall costs } \\
\text { of running the programs }\end{array}$ & 35.6 & 41.1 & 15.1 & 5.5 & 2.7 \\
\hline 7) & $\begin{array}{l}\text { My University large student population enables it to better utilize its } \\
\text { resources e.g. Lecturers and learning facilities }\end{array}$ & 58.9 & 35.6 & 5.5 & 0.0 & 0.0 \\
\hline 8) & $\begin{array}{l}\text { My University large facilities such as campuses enables it to admit larger } \\
\text { student numbers }\end{array}$ & 27.4 & 43.8 & 17.8 & 11.0 & 0.0 \\
\hline 9) & $\begin{array}{l}\text { My University large student population enables it to better negotiate for } \\
\text { learning materials/industrial attachments hence lowering the cost of learning }\end{array}$ & 2.7 & 8.2 & 21.9 & 47.9 & 19.2 \\
\hline 10) & The university has diverse facilities due to student numbers & 30.1 & 46.6 & 11.0 & 12.3 & 0.0 \\
\hline
\end{tabular}

The role of the scale policy on the institutional performance was examined using five metrics that is large student population leading to lowering of overall costs, better resource utilization due to student numbers, large facilities enabling admission of large student numbers, large student numbers leading to better negotiation of learning materials, and diversity of facilities due to student numbers. In the context of the student population leading to lowering of overall cost, a majority of $41.1 \%$ of the respondents agreed that large student population led to lowering of overall cost. This was further collaborated by $35.6 \%$ of the respondents who also strongly agreed with the statements. The size of the university is a source of cost advantage as there is the relationship between firm size measured in terms of volume of production - and costs - measured in terms of average costs per unit of production (Wanjohi, 2012). In the context of the economies of scale, the size of the university is measured in terms of student enrolment and economies of scale arise when the cost of providing education falls as the student enrolment or size of the university increases.

In most universities, the student enrolment levels in either the undergraduate or postgraduate level and the associated teaching output is the essential contributor of costs. In the short term, the universities can achieve economies of scale by lowering quality and boosting quantity (student enrolment), but in the long term the quality of instruction and research output also influence the university cost structure and are vital determinants of economies of scale in higher education (Mwangi, 2013). The optimal volume of production is reached when 
the average costs per unit of production is minimum. Universities with high degree courses and student numbers are able to purchase and utilize services that cannot be used in smaller universities. Cost leadership strategies have traditionally been based upon the economies of scale, gained through sales volume (Imaana, 2011). However, if volume is to be the basis for cost leadership then it is preferable for that volume to be gained early in the market life cycle.

In relations to the large student population enabling better resource utilization, a cumulative percentage of $94.5 \%$ of the population were affirmative that was the case. A large student population is good for efficient resources utilization through the minimal cost per student.On the other hand, in relations to large student population leading to better negotiation of industrial attachment, a cumulative percentage of $67.1 \%$ of the respondents disagreed that large student population led to better negotiation of industrial attachment. Finally, in relations to the university having diverse facilities due to student numbers, a cumulative percentage of $76.7 \%$ of the respondents were affirmative that there was diversity of facilities due to student numbers. However, a small percentage of $12.3 \%$ of the respondents disagreed that the university had diversity of resources as a result of student population. The diversity of facilities within the context of public university occurs due to the large student enrolment especially from government sponsored students making it cost effective for the facilities to serve a wider range of student population. The means and standard deviation of scale policy was examined using table 4 below.

Table 4; Means and Standard Deviation of Scale Policy

\begin{tabular}{|c|c|c|c|c|c|}
\hline & $\mathbf{N}$ & Min & Max & Mean & $\begin{array}{l}\text { Std. } \\
\text { Dev. }\end{array}$ \\
\hline $\begin{array}{l}\text { My University has a large student population hence lowering the overall } \\
\text { costs of running the programs }\end{array}$ & 73 & 1 & 5 & 4.01 & .99 \\
\hline $\begin{array}{l}\text { My University large student population enables it to better utilize its } \\
\text { resources e.g. Lecturers and learning facilities }\end{array}$ & 73 & 3 & 5 & 4.53 & .60 \\
\hline $\begin{array}{l}\text { My University large facilities such as campuses enables it to admit larger } \\
\text { student numbers }\end{array}$ & 73 & 2 & 5 & 3.87 & .94 \\
\hline $\begin{array}{l}\text { My University large student population enables it to better negotiate for } \\
\text { learning materials/industrial attachments hence lowering the cost of learning }\end{array}$ & 73 & 1 & 5 & 2.27 & .96 \\
\hline The university has diverse facilities due to student numbers & 73 & 2 & 5 & 3.94 & .95 \\
\hline Valid N (listwise) & 73 & & & & \\
\hline
\end{tabular}

The means and standard deviation of the scale policy were examined using table 4 above. The university student population enabling it to lower the overall cost of running the programs had the mean of 4.01 and standard deviation of 0.99 implying that on average the respondents tended on average to agree with the given metric. The respondents also tended to strongly agree that the university large student population enabled it to better utilize its resources due to a mean of 4.53 and a standard deviation of 0.60 . On the other hand, the university large facilities enabling it to admit larger student numbers had the respondents on average agreeing due to a mean of 3.87 and a standard deviation of 0.94 . On the other hand, the university large student population enabling a better negotiation of learning materials and attachment had the respondents on average disagreeing due to a mean of 2.27 and a standard deviation of 0.96. Finally, the respondents on average tended to agree that the university had diverse facilities as a result of student population due to a mean of 3.94 and a standard of 0.95 .

\section{Structure Centralization Policy on Institutional Performance}

The frequency distribution of structure centralization policy was examined using table 5 below;

Table 5; Frequency Distribution of Structure Centralization Policy

\begin{tabular}{|c|c|c|c|c|c|c|}
\hline & Centralization Policy & SA & $\mathbf{A}$ & $\mathbf{U}$ & D & SD \\
\hline 11) & $\begin{array}{l}\text { The centralization of marketing services to the head office has minimized } \\
\text { the cost of operations }\end{array}$ & 37.0 & 41.1 & 13.7 & 6.8 & 1.4 \\
\hline 12) & $\begin{array}{l}\text { The centralization of the science degree courses to main campus has } \\
\text { minimized the cost of operations }\end{array}$ & 31.5 & 38.4 & 17.8 & 12.3 & 0.0 \\
\hline 13) & $\begin{array}{l}\text { The centralization of the major finance aspects to the head office has } \\
\text { minimized the costs of operations }\end{array}$ & 35.6 & 38.4 & 16.4 & 9.6 & 0.0 \\
\hline 14) & $\begin{array}{l}\text { The centralization of the graduation services to the main campus has } \\
\text { minimized the cost of operations }\end{array}$ & 57.5 & 34.2 & 8.2 & 0.0 & 0.0 \\
\hline 15) & $\begin{array}{l}\text { Centralization of examination administration to main campuses } \\
\text { minimizes the costs of operations }\end{array}$ & 53.4 & 32.9 & 13.7 & 0.0 & 0.0 \\
\hline
\end{tabular}

The structure centralization policy was examined using five metrics that is centralization of marketing services, centralization of science degree courses, centralization of finance aspects, centralization of graduation services, and centralization of examination administration services. In the context, of centralization of marketing 
services leading to minimization of cost of operations, a cumulative percentage of $78.1 \%$ of the respondents were affirmative that centralization of marketing services did lead to minimization of cost of operations. However, a percentage of $8.2 \%$ of the respondents didn't agree with the statement. The universities normally undertake the marketing services from one central place for all its campuses as opposed to each campus undertaking its individual marketing services. This has the effect of lowering the marketing services cost for the institutions.

In the context of the centralization of science degree leading to minimization of cost of operations, a cumulative percentage of $69.9 \%$ of the respondents were affirmative that centralization of science degree led to minimization of the cost of operations with only $9.6 \%$ of the respondents disagreeing. The science degrees are often costly to run due to the need to create laboratories and other critical facilities. It is therefore cost effective for such courses to be centralized as opposed to be delegated to diverse campuses which sometimes wouldn't recruit sufficient numbers to be commercially viable.

On the other hand, in the context of the centralization of the graduation services to the main campus leading to minimization of cost of operations, $91.7 \%$ of the respondents were affirmative that it led to minimization of costs of operations. The centralization of the graduation services makes it cost effective to undertake the activity in one place due to the logistics levels required and the student numbers involved. Finally, in relations to the centralization of the examination administration leading to the minimization of costs of operations then a majority of the respondents (53.4\%) strongly agreed that the centralization of examination administration led to cost minimization. The mean and standard deviation of structure centralization was examined through the use of table 6 below;

Table 6; Mean and Standard Deviation of Structure Centralization Policy

\begin{tabular}{|c|c|c|c|c|c|}
\hline & $\mathbf{N}$ & Min & Max & Mean & Std. Dev. \\
\hline $\begin{array}{l}\text { The centralization of marketing services to the head office has minimized } \\
\text { the cost of operations }\end{array}$ & 73 & 1 & 5 & 4.05 & .95 \\
\hline $\begin{array}{l}\text { The centralization of the science degree courses to main campus has } \\
\text { minimized the cost of operations }\end{array}$ & 73 & 2 & 5 & 3.89 & .99 \\
\hline $\begin{array}{l}\text { The centralization of the major finance aspects to the head office has } \\
\text { minimized the costs of operations }\end{array}$ & 73 & 2 & 5 & 4.00 & .95 \\
\hline $\begin{array}{l}\text { The centralization of the graduation services to the main campus has } \\
\text { minimized the cost of operations }\end{array}$ & 73 & 3 & 5 & 4.49 & .64 \\
\hline $\begin{array}{l}\text { Centralization of examination administration to main campuses minimizes } \\
\text { the costs of operations }\end{array}$ & 73 & 3 & 5 & 4.39 & .72 \\
\hline Valid N (listwise) & 73 & & & & \\
\hline
\end{tabular}

The mean and standard deviation of the structure centralization policy had a table 6 . The respondents on average tended to agree that the centralization of marketing services to the head office had minimized the cost of operations due to a mean of 4.05 and a standard deviation of 0.95 . On the other hand, the respondents on average tended to agree that the centralization of the science degree courses to main campus had minimized the costs of operations due to a mean of 4.00 and a standard deviation 0.95 . In relations to the centralization of the graduation services to the main campus minimizing the cost of operations, the respondents on average tended to agree that it had an effect due to a mean of 4.49 and a standard deviation of 0.64 . On the other hand, the centralization of the examination administration to main campuses minimizing the costs of operations had a mean of 4.39 and a standard deviation of 0.72 implying that the respondents on average tended to agree with the metric.

\section{Institutional Performance}

The frequency distribution of institutional performance was examined using table 7 below;

Table 7; Frequency Distribution on Institutional Performance in Percentages

\begin{tabular}{|c|c|c|c|c|c|c|}
\hline & Institutional Performance & SA & $\mathbf{A}$ & $\mathbf{U}$ & $\mathbf{D}$ & SD \\
\hline 19) & $\begin{array}{l}\text { My university is able to attract a diverse range of students at undergraduate level } \\
\text { compared to peers }\end{array}$ & 56.2 & 32.9 & 11.0 & 0.0 & 0.0 \\
\hline 20) & $\begin{array}{l}\text { My university is able to attract a diverse range of students at postgraduate level } \\
\text { compared to peers }\end{array}$ & 34.2 & 38.4 & 15.1 & 12.3 & 0.0 \\
\hline 21) & My university is able to required numbers across its different courses and programs & 34.2 & 37.0 & 19.2 & 9.6 & 0.0 \\
\hline 22) & My university is able to attract students to all its outlets & 35.6 & 39.7 & 17.8 & 6.8 & 0.0 \\
\hline
\end{tabular}

The institutional performance was examined using four metrics that is ability to attract diverse range of students at undergraduate level compared to peers, ability to attract diverse range of postgraduate students compared to peers, ability to acquire required number of students across different courses and programs, and the ability of the university to attract students to all its outlets. In this context, a majority of the respondents $56.2 \%$ 
strongly agreed that their university were able to attract a diverse range of students at undergraduate level compared to peers. This was further collaborated by $32.9 \%$ of the respondents who were also in agreement. On the other hand, a cumulative percentage of $72.6 \%$ of the respondents were affirmative that the university was able to attract a diverse range of students at postgraduate level compared to peers. This is in contrast to the $12.3 \%$ of the respondents who disagreed on the same. In the context of the university being able to attract required numbers across its different courses and programs, a cumulative percentage of $71.2 \%$ of the respondents were affirmative that the university was able to attract students to all its outlets. This is in contrast to the $6.8 \%$ of the respondents who disagreed on the statement. The means and standard deviation of institutional performance was examined using table 8 below;

Table 8; Means and Standard Deviation of Institutional Performance

\begin{tabular}{|c|c|c|c|c|c|}
\hline & $\mathrm{N}$ & Min & Max & Mean & Std. Dev. \\
\hline $\begin{array}{l}\text { My university is able to attract a diverse range of students at undergraduate } \\
\text { level compared to peers }\end{array}$ & 73 & 3 & 5 & 4.45 & .68 \\
\hline $\begin{array}{l}\text { My university is able to attract a diverse range of students at postgraduate } \\
\text { level compared to peers }\end{array}$ & 73 & 2 & 5 & 3.94 & .99 \\
\hline $\begin{array}{l}\text { My university is able to required numbers across its different courses and } \\
\text { programs }\end{array}$ & 73 & 2 & 5 & 3.95 & .96 \\
\hline My university is able to attract students to all its outlets & 73 & 2 & 5 & 4.04 & .90 \\
\hline Valid N (listwise) & 73 & & & & \\
\hline
\end{tabular}

The means and standard deviations of institutional performance were examined using table 8 above. The respondents tended on average to agree that the university was able to attract a diverse range of students at an undergraduate level compared to peers due to a mean of 4.45 and a standard deviation of 0.68 . On the other hand, the respondents on average tended to agree that the university is able to attract a diverse range of students at post graduate level compared to peers due to a mean of 3.94 and a standard deviation of 0.99 . On the other hand, the university having the required numbers across its different courses and programs had a mean and standard deviation of 3.95 and 0.96 implying that the respondents on average tended to agree with the given metric. Finally, the respondents tended on average to agree that the university was able to attract students to all its outlets due to a mean of 4.04 and a standard deviation of 0.90 .

\section{Inferential Statistics}

The inferential statistics that were undertaken include the one way ANOVA for hypothesis testing, the linear correlation and multiple linear regression statistics.

\section{Hypothesis Testing}

The hypothesis testing of this study utilized the one way ANOVA in which the indicators of individual variables were regressed against the composite variable of institutional performance. Both the critical value method and $\mathrm{p}$ value method were used in hypothesis testing. In the context of the critical value method, the $\mathrm{F}$ ratio was examined and if $\mathrm{F}$ observed $\left(\mathrm{df}_{\mathrm{Num}} \mathrm{df}\right.$ Demon $) \geq \mathrm{F}_{\alpha}\left(\mathrm{df} \mathrm{Num}_{\text {, }} \mathrm{df}\right.$ Denom $)$ then the model is a good fit or predictor of the dependent variable and the null hypothesis was rejected. On the other hand, in the context of the $\mathrm{p}$ value, the $\mathrm{p}$ value of the ANOVA table was ten compared to the significance level $(\alpha)$ of 0.05 and the null hypothesis rejected if $\mathrm{p}$ value $<\alpha$ that is $\mathrm{p}$ value $<0.05$.

$\boldsymbol{H}_{01}$ : There is no significant relationship between pricing policy and institutional performance in public universities in Kenya

Table 9; ANOVA of Pricing Policy

\begin{tabular}{|l|l|l|l|l|l|l|}
\hline Model & Sum of Squares & df & Mean Square & F & Sig. \\
\hline \multirow{3}{*}{1} & Regression & 17.854 & 5 & 3.571 & 37.599 & $.000^{\mathrm{b}}$ \\
\cline { 2 - 8 } & Residual & 6.363 & 67 & .095 & & \\
\cline { 2 - 7 } & Total & 24.217 & 72 & & & \\
\hline
\end{tabular}

The table shows that the model is a good fit for data since $\mathrm{F}_{\text {Observed }}(5,67)=37.599$ and $\mathrm{F}_{\alpha}(5,67)=$ 2.35 (as observed from $\mathrm{F}$ distribution table), then $\mathrm{F}$ Observed $\left(\mathrm{df}_{\mathrm{Num}} \mathrm{df} \mathrm{Demon}_{\mathrm{D}}\right) \geq \mathrm{F}_{\alpha}\left(\mathrm{df}_{\mathrm{Num}}, \mathrm{df} \mathrm{Denom}_{\text {Deading to a }}\right.$ conclusion that the model is a good predictor of dependent variable. Therefore, the null hypothesis $\left(\boldsymbol{H}_{01}\right)$ that there is no significant relationship between pricing policy and institutional performance in public universities in Kenya was rejected and the alternative hypothesis accepted. On the other hand, the p value of $0.000<0.05$ further collaborated the decision to reject the null hypothesis since there was a $0.000 \%$ likelihood or probability that the model will give a wrong prediction of institutional performance and therefore the model was found to a good fit of the data. 
$\boldsymbol{H}_{02}:$ There is no significant relationship between scale policy and the institutional performance in public universities in Kenya

Table 10; ANOVA for Scale Policy

\begin{tabular}{|l|l|l|l|l|l|l|}
\hline \multicolumn{2}{|l|}{ Model } & Sum of Squares & df & Mean Square & F & Sig. \\
\hline \multirow{5}{*}{1} & Regression & 19.184 & 5 & 3.837 & 51.065 & $.000^{\mathrm{b}}$ \\
\cline { 2 - 7 } & Residual & 5.034 & 67 & .075 & & \\
\cline { 2 - 6 } & Total & 24.217 & 72 & & & \\
\hline
\end{tabular}

The table shows that the model is a good fit for data since $F_{\text {Observed }}(5,67)=51.065$ and $F_{\alpha}(5,67)=$ 2.35 (as observed from $\mathrm{F}$ distribution table), then $\mathrm{F}$ Observed $\left(\mathrm{df}_{\mathrm{Num},} \mathrm{df} \mathrm{Demon}\right) \geq \mathrm{F}_{\alpha}\left(\mathrm{df}_{\mathrm{Num}}\right.$, $\mathrm{df} \mathrm{Denom}_{\text {Deading to a }}$ conclusion that the model is a good predictor of dependent variable. Therefore, the null hypothesis $\left(\boldsymbol{H}_{\mathbf{0 2}}\right)$ that there is no significant relationship between scale policy and institutional performance in public universities in Kenya was rejected and the alternative hypothesis accepted. On the other hand, the $p$ value of $0.000<0.05$ further collaborated the decision to reject the null hypothesis since there was a $0.000 \%$ likelihood or probability that the model will give a wrong prediction of institutional performance and therefore the model was found to a good fit of the data.

$\boldsymbol{H}_{03}$ : There is no significant relationship between structure centralization policy and the institutional performance in public universities in Kenya

Table 11; ANOVA of structure centralization policy

\begin{tabular}{|l|l|l|l|l|l|l|}
\hline Model & Sum of Squares & df & Mean Square & F & Sig. \\
\hline \multirow{4}{*}{1} & Regression & 22.594 & 5 & 4.519 & 186.429 & $.000^{\mathrm{b}}$ \\
\cline { 2 - 7 } & Residual & 1.624 & 67 & .024 & & \\
\cline { 2 - 6 } & Total & 24.217 & 72 & & & \\
\hline
\end{tabular}

The table shows that the model is a good fit for data since $\mathrm{F}_{\text {Observed }}(5,67)=186.429$ and $\mathrm{F}_{\alpha}(5,67)=$

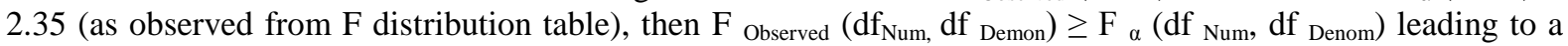
conclusion that the model is a good predictor of dependent variable. Therefore, the null hypothesis $\left(\boldsymbol{H}_{03}\right)$ that there is no significant relationship between structure centralization policy and the institutional performance in public universities in Kenya was rejected and the alternative hypothesis accepted. On the other hand, the $\mathrm{p}$ value of $0.000<0.05$ further collaborated the decision to reject the null hypothesis since there was a $0.000 \%$ likelihood or probability that the model will give a wrong prediction of institutional performance and therefore the model was found to a good fit of the data.

\section{Multiple Linear Regression}

The effect of the three independent variable on the dependent variable was examined using the multiple linear regression. The multiple correlation coefficient is used to measure the relationship between the independent variables and the dependent variable. In this context, the multiple correlation coefficient (R) is positive indicating a positive correlation between the cumulative effect of the three independent variables on the dependent variable. The multiple correlation effect of 0.947 indicates a relatively strong positive relationship effect between the three independent variables (Structure Centralization, Pricing, Scale policy) and the dependent variable (institutional performance). On the other hand, the coefficient of determination (R Square) indicates the variance on the dependent variable attributed to the three independent variables. In this context, the coefficient of determination (R Square) of 0.896 indicates that the three independent variables contributed to $89.6 \%$ of the variance in dependent variable. This would indicate that there are other variables that attributed to $10.4 \%$ variance in the institutional performance of public universities.

Table 12; Model Summary

\begin{tabular}{|l|l|l|l|l|}
\hline Model & R & R Square & Adjusted R Square & Std. Error of the Estimate \\
\hline 1 & $.947^{\text {a }}$ & .896 & .892 & .19067 \\
\hline
\end{tabular}

The model was examined on whether it is a good fit for data through examination of the $\mathrm{F}$ ratio and $\mathrm{p}$ value. In this context, since the $F$ Observed $(3,69)=199.035$ and $F_{\alpha}(3,69)=2.74$ (as observed from $F$ distribution table), then $\mathrm{F}_{\text {Observed }}\left(\mathrm{df}_{\mathrm{Num}}, \mathrm{df}_{\text {Demon }}\right) \geq \mathrm{F}_{\alpha}\left(\mathrm{df}_{\mathrm{Num}}, \mathrm{df}_{\text {Denom }}\right)$ leading to a conclusion that the model is a good fit for data or good predictor of dependent variable. On the other hand, the p value of $0.000<0.05$ further 
collaborated the decision to reject the null hypothesis since there was a $0.000 \%$ likelihood or probability that the model will give a wrong prediction of institutional performance and therefore the model was found to a good fit of the data.

Table 13; ANOVA

\begin{tabular}{|l|l|l|l|l|l|l|}
\hline Model & Sum of Squares & df & Mean Square & F & Sig. \\
\hline \multirow{4}{*}{1} & Regression & 21.709 & 3 & 7.236 & 199.035 & $.000^{\mathrm{b}}$ \\
\cline { 2 - 6 } & Residual & 2.509 & 69 & .036 & & \\
\cline { 2 - 6 } & Total & 24.217 & 72 & & & \\
\hline
\end{tabular}

The unstandardized multiple linear regression coefficients were examined in order to determine the effect of individual independent variables with the other variables kept constant. The results indicated that pricing and scale policy had a negative variance on the institutional performance of the universities with the other variables kept constant. However, structure centralization had a positive variance on the institutional performance of public universities with the other independent variables kept constant.

Institutional Performance $=-0.054-0.021\left(x_{1}\right)-0.062\left(x_{2}\right)+1.069\left(x_{3}\right)$ where

$x_{1=}$ Pricing Policy

$x_{2}=$ Scale Policy

$x_{3}=$ Structure Centralization

The coefficient of intercept of -0.054 implies that implies that if the pricing policy, scale policy and structure centralization policy are kept at zero then the institutional performance of the public universities would be at -0.054 . On the other hand, a unit increase in pricing policy would lead to a 0.021 decrease in institutional performance. Similarly, a unit increase in scale policy would lead to a 0.062 decrease in institutional performance. Finally, a unit increase in structure centralization would lead to a 1.069 increase in institutional performance. The significance of the independent variables as predictors of dependent variable occurs if the absolute t-value of the regression coefficient associated with that independent variable is greater than the absolute critical $t$-value that is $t_{0}>t_{\alpha / 2, n-2}$. Therefore, in the context of pricing policy, the absolute $t_{0}$ is 0.302 while $\mathrm{t}_{0.025,1}=6.314$ and as such the absolute $\mathrm{t}_{\mathrm{o}}<\mathrm{t}_{\alpha / 2, \mathrm{n}-2}$ indicating that pricing structure was not a significant predictor of institutional performance. This was also collaborated through the use of $p$ value of 0.763 being greater that the significance level of 0.05. In the context of Scale policy, the absolute $t_{0}$ is 0.604 while $t_{0.025,1}$ $=6.314$ and as such the absolute $t_{0}<t_{\alpha / 2, n-2}$ indicating that scale policy was not a significant predictor of institutional performance. This was also collaborated through the use of $\mathrm{p}$ value of 0.548 being greater that the significance level of 0.05 . In the context of structure centralization, the absolute $t_{0}$ is 17.820 while $t_{0.025,1}=6.314$ and as such the absolute $t_{o}>t_{\alpha / 2}, n-2$ indicating that structure centralization was a significant predictor of institutional performance. This was also collaborated through the use of $p$ value of 0.000 being less than the significance level of 0.05 .

Table 14; Coefficients

\begin{tabular}{|c|c|c|c|c|c|c|}
\hline \multicolumn{2}{|c|}{ Model } & \multicolumn{2}{|c|}{ Unstandardized Coefficients } & \multirow{2}{*}{$\begin{array}{l}\text { Standardized Coefficients } \\
\text { Beta }\end{array}$} & \multirow[t]{2}{*}{$\mathbf{t}$} & \multirow[t]{2}{*}{ Sig. } \\
\hline & & B & Std. Error & & & \\
\hline \multirow[t]{4}{*}{1} & (Constant) & -.054 & .216 & & -.252 & .802 \\
\hline & Pricing & -.021 & .069 & -.020 & -.302 & .763 \\
\hline & Scale & -.062 & .102 & -.043 & -.604 & .548 \\
\hline & $\begin{array}{l}\text { Structure } \\
\text { Centralization }\end{array}$ & 1.069 & .060 & .989 & 17.820 & .000 \\
\hline
\end{tabular}

\section{Recommendations}

The study found that the few items that were brought at the point of entry had the strongest mean amongst the pricing policy. The study therefore recommends that few items requirements should be maintained for the purposes of optimum institutional performance. The study found that the large student population enabling a better utilization of its resources had the highest mean amongst the scale policy. The study therefore recommended that the better utilization should be strived for by the public universities in order to maintain an optimum institutional performance. Finally, in relations to the structure centralization policy the universities should continue to hold centralized graduation ceremonies for optimum performance. 


\section{References}

[1]. Abdi, A. (2014). Strategic Planning and Performance of Banks in Kenya: A Case of National Bank of Kenya. Journal of Emerging Issues in Economics, Finance and Banking (JEIEFB), 2(3), 25-35.

[2]. Agumbi, P. (2013). Challenges and Practices of Strategy Implementation at Technical University of Mombasa. Journal of Modern African Studies, 2(4).

[3]. Annor, K. (2012). An Assessment of the Service Quality Delivery in Tertiary Education-A Case Study of Pentecost University College, Ghana. Journal of Management and Business Studies, 2(3), 30-35.

[4]. Anyim, M. (2012). Gaining Sustainable Competitive Advantage Through Service Differentiation Among Private Hospitals in Nairobi. Journal of Management and Business Studies, 2(2), 65-70.

[5]. Chepkiyeng, F. (2009). Analysis of Strategic Responses of Commercial Banks Towards Attaining Competitive Advantage in Kenya. International Journal of Social Sciences and Enterpreneurship, 2(3), 29-35.

[6]. Gikunda, J. (2014). Determinants of Organizational Performance By Tier Three Commercial Banks in Kenya. International Journal for Management Science and Terchnology, 2(3), 27-35.

[7]. Gitau, A. (2014). Agency Banking and Operational Performance of Commercial Banks in Kenya. International Journal of Business and Social Research, 2(3), 17-25.

[8]. Imaana, E. (2011). The Effects of Competitive Strategies on the Performance of Commercial Banks in Meru Town, Kenya. Journal of Emerging Issues in Economics, Finance and Banking (JEIEFB), 1(3), 29-35.

[9]. Irungu, M. (2010). The Relationship Between Organizational Learning and Performance of Christian Health Association of Kenya Hospitals. International Journal for Management Science and Terchnology, 2(3), 25-37.

[10]. Katamei, J. (2015). Student Perception of Service Delivery at Moi University: A Case Study of Privately Sponsored Student Programme (PSSP) in Eldoret West Campus, Kenya. Journal of Education, 3(5), 49-64.

[11]. Kinanga, R. (2013). Information Technology Adoption Determinants in Improving Human Resource Function in Kenyan Public Universities. International Journal of Business and Management Invention, 4(2), 40-47.

[12]. Kiptui, J. (2012). The Role of Organizational Culture in the Relationship Between Strategy and Perfromance of Commercial Banks in Kenya. Journal of Accounting and Finance, 1(1), 67-69.

[13]. Kitum, K. (2010). Management Perception of Performance Contracting in the University of Nairobi. International Journal of Business and Public Management, 3(4), 23-29.

[14]. Kuria, M. (2013). Operational Challenges Facing Performance of Thermal Power Plants in kenya. Journal of Small Business Management, 2(3), 45-49.

[15]. Mbithi, M. (2014). Transformational Leadership, Organizational Characteristics, Employee Outcomes, Leader-Member Relations and Perfromance of Universities in Kenya. International Journal of Business and Social Sciences, 1(2), 34-39.

[16]. Messah, O. B., \& Immaculate, M. J. N. (2011). Effect of Selected Marketing Communication Tools on Student Enrolment in Private Universities in Kenya. European Journal of Business and Management, 3(3), 172-206. Retrieved from http://www.iiste.org/Journals/index.php/EJBM/article/view/277

[17]. Mnjala, D. M. (2014). The Challenges of Creating Sustainable Competitive Advantage in the Banking Industry in Kenya. IOSR Journal of Business and Management Ver. I, 16(4), 2319-7668. Retrieved from www.iosrjournals.org

[18]. Mucai, G., Kinya, G., Noor, A., \& James, E. (2014). Tax Planning and Financial Performance of Small Scale Enterprises in Kenya. International Review of Management and Business Research, 2(3), 78-85.

[19]. Muia, P. (2012). Influence of Headteachers' Leadership Styles on Pupils' Perfromance in Kenya Certificate of Primary Education in Mbooni Division, Kenya. International Journal of Education and Research, 2(3), 15-22.

[20]. Mukokho, A. (2010). The Influence of Strategic Planning on Performance of Public Universities in Kenya: The Case of University of Nairobi. International Journal of Research in Management, Economics and Commerce, 3(3), 32-35.

[21]. Mulwa, J. (2010). Competitive Strategies Adopted by Small and Medium Sized Horticultural Exporting Companies in Nairobi. Journal of Management Research.

[22]. Munyaka, S. (2013). Influence of Headquarters' Leaqdership Styles on Pupils Perfromance at kenya Certificate of Primary Education at Kathiani District, Kenya. International Journal of Business, Humanities and Technology, 1(2), 26-29.

[23]. Muriithi, G. (2010). Effects of Organizational Structure on Strategy Implementation; A Survey of Commercial Banks in Kenya. Journal of Business and Management, 2(3), 12-16.

[24]. Muthike, J. (2014). Relationship Between Leadership Style and Perfromance of Public Secondary Schools in Makueni County, Kenya. Journal of Business and Management, 1(2), 17-24.

[25]. Muthimi, J. (2013). Challenges Faced by Kenyatta University in Implementing its Competitive Strategies. International Journal of Education and Research, 2(4), 25-30.

[26]. Muthoni, E. (2013). Effects of Organizational Culture on Strategy Implementation in Commercial Banks in Kenya. International Multidisciplinary Journal, 2(3), 17-24.

[27]. Mutiso, A. (2013). Challenges of Implementation of Growth Strategies at the University of Nairobi. International Journal of Research in Management, Economics and Commerce, 3(3), 12-15.

[28]. Mwandebe, C. (2009). An Investigation of Factors that Influence Organizational Transformnation within the Commercial Banking Sector in Kenya. International Journal of Business, Humanities and Technology, 1(1), 17-24.

[29]. Mwangi, L. (2013). Factors Affecting Strategy Implementation in Public Universities in Kenya. International Journal of Management and Strategy, 53(9), 75-80.

[30]. Naisiae, K. (2013). Influence of Principals' Leadership Styles on Students' Kenya Certificate of Secondary Examination Performance in Kajiado North District, Kajiado County, Kenya. International Journal of Business, Humanities and Technology, 2(3), 89-95.

[31]. Ndanu, R. (2014). Determinants of Competitive Advantage Among Private Universities in Kenya. Journal of Economics and International Business Research, 2(2), 17-20.

[32]. Ngati, J. (2014). Positioning Strategy as a Source of Competitive Advantage to Private Universities in Kenya. Interdisciplinary Journal of Contemporary Research in Business, 2(3), 25-30.

[33]. Nkirote, M. (2014). Marketing Strategies Adopted to Gain a Competitive Advantage by Supermarkets in Kakamega Town, Kenya. International Journal of Business and Social Research, 3(4), 78-85.

[34]. Nyakango, M. (2013). Competitive Strategies Adopted by Audit Firms in Nairobi. International Journal of Social Sciences and Entrepreneurship, 2(3), 23-29.

[35]. Nyongesa, L. (2014). Head Teacher's Leadership Style on School Academic Perfroamance in Kenyan Secondary Schools. International Journal of Business and Social Sciences, 2(3), 12-19.

[36]. Oduor, C., In, S., Fulfillment, P., The, O. F., For, R., Award, T. H. E., ... Business, O. F. (2015). Total Quality Management and 
Performance of Public Universities in Kenya Requirements for the Award of Master of Business Administration Degree in Opreations Management By the.

[37]. Ogoye, J. (2013). Infleunce of Quality Management Systems Implementation on Organizational Performance: (Case Study of South Nyanza Sugar Company Limited Migori County, Kenya). International Journal of Business and Social Sciences, 2(3), 49-55.

[38]. Omollo, D. (2013). Competitive Strategies Applied by Bank Agents to Sustain Their Market Share (A Case of Commercial Banks in Migori County). International Journal of Social Sciences and Entrepreneurship, 4(2), 35-39.

[39]. Riechi, A. R. O. (2013). Demand for academic programmes offered in Kenya's public universities and their relevance to the labour market. Educational Research and Reviews, 2(1), 15-25.

[40]. Riungu, K. (2013). Relationship Between Training and Development and Competitive Advantage in the Microfinance Industry. Human Resource Management Journal, 2(3), 1-8.

[41]. Sathyamoorthi, J. (2016). An Analysis of Supermarket Pricing: The Case of Selected Supermarkets in Gaborone, Botswana. Journal of Management Research, 8(2), 66-74. http://doi.org/10.5296/jmr.v8i2.9089

[42]. Sifuna, I. (2014). Effect of Competitive Strategies on Performance of Public Universities in Kenya. Journal of Accounting and Finance, 3(4), 19-25.

[43]. Sirengo, S. (2009). Sustainable Competitive Advantage Arising from Competitive Strategies adopted by Low-cost Airlines in Kenya: Case of Five Forty Aviation Limited. Journal of Management Research.

[44]. Tholkes, R. J., \& Sederberg, C. H. (2015). Economies of scale and rural schools. Research in Rural Education, 7(1), 9-15.

[45]. Tirivayi, N., Groot, W., \& Brink, H. M. van den. (2009). Size and Economies of Scale in Higher Education and the Implications for Mergers. Tier Working Paper Series, 2(3), 15-30. Retrieved from http://www.tierweb.nl/assets/files/UM/TIER_WP 12-09.pdf

[46]. Waema, M. (2013). The Effects of Competitive Strategies on Performance of Dairy Firms in Kenya. International Multidisciplinary Journal, 1(1), 15-17.

[47]. Waiganjo, W. (2013). Effect of Competitive Strategies on the Relationship Between Strategic Human Resource Management and Firm Performance of Kenya'S Corporate Organizations. Journal of Business and Organizational Development, 1(1), 65-70.

[48]. Wanjohi, A. (2012). An Investigation on Factors IOnfluencing Choice of Competitive Strategies in Transport Saccos: A Survey of Transport Saccos in Nyeri Central District. Journal of Business and Management, 2(2), 33-36.

[49]. Wanyonyi, W. (2012). The Competitive Strategies of Bamburi Portland and Cement, East African Portland Cement and Athi River Mining Cement Firms in Kenya. Journal of Management Research, 2(3), 39-42.

[50]. Wu, M. (2010). The search for sustainable competitive advantage : A stakeholder management perspective. Journal of Business and Management, 2(3), 45-50.

[51]. Yongtao, T. (2009). Contractor's Competitiveness and Competitive Strategy in Hong Kong. ProQuest LLC.

[52]. Yoon, Y. (2012). Development of a Structural Model for Tourism Destination Competitiveness from Stakeholders' Perspectives. Journal of Marketing, 2(3), 213-215. 